\title{
PERSEPSI WISATAWAN TERHADAP EKSISTENSI KAWASAN WISATA ALAM PANTAI PANDAWA DESA KUTUH BADUNG BALI
}

\author{
A. Agung Putu Swabawa, I Nyoman Meirejeki, \\ Jurusan Pariwisata, Politeknik Negeri Bali, Badung, Bali-Indonesia \\ Email: putuswabawa@pnb.ac.id \\ Made Setena,Prodi Manajemen Universitas Warmadewa,denapasar Bali Indonesia
}

\section{How to cite (in APA style):}

A.Agung Putu Swabawa, I Nyoman Meirejeki. (2021). Persepsi Wisatawan Terhadap Eksistensi Kawasan Wisata Alam Pantai Pandawa Desa Kutuh Badung Bali. Warmadewa Management and Business Journal, 3(1) pp.85-99.

\section{Abstract}

This research was conducted in the tourist area of Pandawa beach, Kutuh village, South Kuta district, Badung. The purpose of this study is to describe the potential and tourist attractions on the Pandawa beach and to find out the perceptions of tourists towards tourism products on the Pandawa beach which can later be used as a consideration in improving the management of the Pandawa beach area.

Data collection was carried out using the survey method, questionnaire, conducting interviews with both managers and tourists. Data were analyzed using quantitative analysis techniques, namely analysis techniques for analyzing quantitative data using descriptive statistics used to measure a person's characteristics, opinions and perceptions.

The results of the analysis show the potential and attractiveness of Pandawa Beach which can be developed into a tourist area or tourism product, including: towering limestone cliffs, white sandy beaches, seaweed, clear blue sea, coral garden. . Creative tourism products that can be developed by looking at the potential that exists on the Pandawa beach are maritime museums and grass cultivation and culinary tours. The perception of tourism towards the natural conditions of the Pandawa beach as a whole is in a good category, but there is still the perception of foreign tourists in the sufficient category of public infrastructure that needs the attention of Pandawa beach management. So in order to increase the popularity of the Pandawa beach area, it is necessary to do the following: organize the natural environment on the Pandawa beach, need to preserve existing customs and increase the creation of cultural arts, increase the capacity, number and quality of public infrastructure, increase the number and quality tourism facilities, and improve environmental management and operational management of the Pandawa coast based on professionalism.

Keywords: Potential, perception, creative tourism products, popularity, management

\begin{abstract}
Abstrak
Penelitian ini dilakukan di kawasan wisata pantai Pandawa desa Kutuh, kecamatan Kuta Selatan, Badung. Tujuan penelitian ini adalah Mendiskripsikan potensi-potensi dan daya tarik wisata yang ada di pantai Pandawa dan untuk mengetahui persepsi wisatawan terhadap produk wisata yang terdapat pantai Pandawa yang nantinya bisa digunakan sebagai bahan pertimbangan dalam melakukan perbaikan pengelolaan Kawasan pantai Pandawa.
\end{abstract}


Pengumpulan data yang dilakukan dengan menggunakan metode metode servey, kuesioner, melakukan wawancara baik dengan pengelola maupun dengan wisatawan. Data dianalisis dengan teknik analisis kuantitatif, yaitu teknik analisis untuk menganalisa data kuantitatif dengan menggunakan statistik deskriptif yang digunakan untuk mengukur sifat, pendapat dan persepsi seseorang

Dari hasil analisis menunjukkan Potensi dan daya tarik yang terdapat di Pantai Pandawa yang bisa dikembangkan menjadi kawasan wisata atau produk wisata, meliputi: tebing kapur yang menjulang tinggi, pantai berpasir putih, rumput laut, laut biru yang jernih, taman terumbu karang (coral garden). Produk wisata kreatif yang bisa dikembangkan dengan melihat potensi yang ada di pantai Pandawa adalah museum bahari dan wisata budi daya dan kuliner rumput. Persepsi wisatawaan terhadap kondisi alam pantai Pandawa secara keseluruhan dalam katagori baik, namun masih ada persepsi wisatawan asing dalam katagori cukup terhadap prasarana umum yang perlu mendapatkan perhatian manajemen pantai Pandawa. Maka dalam rangka meningkatkan popularitas kawasan pantai Pandawa, perlu melakukan beberapa hal sebagai berikut: menata lingkungan alam yang ada di pantai Pandawa, perlu melestarikan adat istiadat yang ada dan meningkatkan kreasi seni budaya, meningkatkan kapasitas, jumlah dan kualitas prasarana umum, meningkatkan jumlah dan kualitas sarana paraiwisata, dan merperbaiki manajemen lingkungan dan manajemen operasional pantai Pandawa yang berbasis profesionalisme

\section{Kata kunci: Potensi, persepsi, produk wisata kreatif, popularitas, pengelolaan.}

\section{PENDAHULUAN}

Pantai Pandawa adalah salah satu kawasan wisata di Desa Kutuh, berjarak kurang lebih $3 \mathrm{~km}$ dari kawasan Wisata Nusa Dua dan Pura Uluwatu. Pantai ini lokasinya tersembunyi di balik deretan perbukitan batu yang hanya ditumbuhi semak-belukar, akan tetapi Pemkab Badung menyadari potensi wisata yang dimiliki pantai Pandawa. Tahun 2002 mulai dibuatkan jalan akses menuju Pantai Pendawa dan pendataan sehingga mudah untuk dilalui kendaraan serta dapat menarik minat para pengunjung.

Bulan Desember tahun 2012 Pantai Pandawa secara resmi mulai dibuka yang diawali dengan vestival Pandawa Beach. Potensi yang dimiliki berupa: pemandangan pantai dengan pasir putih yang bersih, serta ombak yang tenang, bebas dari polusi dan pedagang acung sehingga para wisatawan dapat melakukan aktivitas wisata bahari dengan leluasa. Banyak bermunculan warung makan yang menjual nasi goreng, mie goreng, ikan laut bakar dan beberapa jenis makanan barat, warung makanan menyediakan kursi berjemur berserta payung yang dapat disewa. Dengan adanya pengembangan yang dilakukan oleh Pemkab. Badung, Desa Kutuh dan Badan Pengelola Pantai Pendawa, membuahkan hasil yang dapat dilihat dari tingkat kunjungan wisatawan semakin banyak. Di mana tingkat kunjungan wisatawan baik wisatawan manca negara maupun domestik dari bulan Pebruari 2017 sampai dengan bulan Januari 2018 cukup berfluktuasi dimana pada bulan April, Juli, September dan Oktober mengalami penurunan, akan tetapi secara keseluruhan mengalami peningkatan sebesar 26,59\% untuk wisatawan domestik dan 34,37\% untuk wisatawan manca Negara. Selama dua belas bulan dari Pebruari 2017 sampai dengan bulan Januari 2014, rata-rata tingkat kunjungan per bulannya sebesar 32.760 orang untuk wisatawan domestik dan 4.603 orang untuk wisatawan manca Negara. 
Pantai Pendawa memiliki lokasi yang strategis, jika dihubungkan dengan konsep 4A, yakni jarak dan waktu tempuh menuju destinasi diukur dari bandara "accesable" dari bandara Ngurah Rai Tuban dan hotel di Badung selatan. Daya tarik wisata "attractions", pantai Pendawa memiliki potensi untuk atraksi wisata bahari dan paralayang, adanya fasilitas pendukung pariwisata "amenities, yang saat ini masih sedang pembenahan serta adanya lembaga pariwisata "ancillary" yaitu badan pengelola pantai Pendawa. Membangun pariwisata di Pantai Pandawa berarti sepakat pula harus membangun daya tarik wisata "attractions" khususnya daya tarik wisata man-made, sementara untuk daya tarik alamiah dan budaya hanya diperlukan penataan dan pengkemasan. Karena jarak dan waktu tempuh menuju destinasi "accesable" yang dekat dengan Bandara Ngurah Rai akhirnya akan mendorong pemerintah untuk membangun jalan raya yang layak untuk angkutan wisata menuju Pantai pandawa, yang saat ini pengerjaan jalan menuju Pantai Pandawa sudah dimulai, sementara fasilitas pendukung pariwisata "amenities" seperti hotel, penginapan, restoran juga sudah mulai disiapkan.

Dengan banyaknya kunjungan wisatawan ke Pantai Pandawa, maka diterbitkannya Surat Keputusan Bersama Perbekel Desa Kutuh dan Bendesa Adat Kutuh Nomor 01 Tahun 2013 tentang Penyempurnaan Atas Pembentukan Tim Penataan Kawasan Pantai Kutuh (PKPK) yang mengatur tentang penataan kawasan Pantai Kutuh yang meliputi Pantai Pandawa, Pantai Timbis dan Pantai Gunung Payung. Secara sfesifik, pembentukan Tim Penataan Kawasan Pantai Kutuh menetapkan hak, kewajiban dan wewenang yang meliputi: 1) Kewajiban yang terdiri dari : a) melaksanakan pendataan dan pemetaan tentang potensi yang ada di kawasan pantai kutuh , b) membuat master plan dan detail plan, c) menyusun program kerja, pengelompokan aktivitas kegiatan dan melaksanakan kegiatan fisik sesuai dengan kebutuhan dilapangan yang mengacu pada Rpjm-Desa 2010 - 2015, d) melakukan penataan, pengawasan dan pembinaan terhadap kegiatan yang ditimbulkan oleh masyarakat atau kelompok di kawasan Pantai Kutuh sesuai dengan batasan kewenangan, e) melaksanakan pengelolaan sumber-sumber pendapatan terkait dengan aktivitas yang ada, selama belum ditetapkannya badan pengelola khusus, f) merekrut petugas yang dibutuhkan sesuai dengan kebutuhan dan kondisi keuangan yang ada, g) melaporkan pelaksanaan tugas kepada perbekel kutuh dan Bendesa adat kutuh setiap bulan, 2) Hak yang terdiri dari: a) dapat mengelola dana oprasional yang menyangkut biaya penataan, biaya opersaional teknis dan biaya oprasional lainnya, yang bersumber dari hasil pengelolaan kawasan pantai kutuh atau sumber pendapatan lainnya yang diberikan oleh pemerintah Desa Dinas dan Desa Adat Kutuh dan bantuan pihak ketiga sesuai ketentuan yang diberikan oleh perbekel dan Bendesa Adat Kutuh, b) dana operasinal tersebut pada huruf a diatas dalam peruntukannya dapat diatur lebih lanjut olehTim PKPK, 3) wewenang yang terdiri dari: a) untuk meningkatkan pengelolaan Tim PKPK dapat bekerja sama dengan pihak lembaga desa atau pihak lain dengan terlebih dahulu berkoordinasi dengan Perbekel Kutuh dan Bendesa Adat Kutuh, b) mengusahakan sumber-sumber pendapatan lainnya untuk menopang biaya penataan dan biaya oprasional Tim PKPK.

Sebagai destinasi pariwisata baru Tim Penataan Kawasan Pantai Kutuh bersama dengan pemerintah Desa Dinas, Desa Adat Kutuh bersama Pemda Tingkat II Badung mulai 
menata pantai Pendawa dengan harapan agar menjadi objek dan daya tarik menarik bahkan menjadi surga baru di Pulau Dewata. Namun demikian, agar penataan dan perkembangannya sesuai dengan keinginan pasar, pengembangannya terarah, sejalan dengan makna Sapta Pesona yang telah ditetapkan dengan Keputusan Menteri Pariwisata, Pos dan Telekomunikasi Nomor: KM.5/UM.209/MPPT-89 yang bisa menciptakan rasa aman,Ketertiban,Kebersihan, Kesejukan, Keindahan, Keramahan, dan Kenangan yang nantinya diharapkan akan bisa menjadi objek wisata unggulan dan berkelanjutan.Untuk itu perlu kiranya diekflorasi potensi yang dimiliki, dicarikan input kepada para pelaku pariwisata, akademisi dan wisatawan untuk disusun blueprint pengembangan produk wisata kreatif di Pantai Pendawa. Kawasan wisata pantai Pandawa mempunyai Kenggulan berupa: pemandangan tebingnya yang menakjubkan, air lautnya masih bersih, adanya trumbu karang yang masih alami, sedangkan kelemahannya berupa: penataan lingkungan yang kurang baik dan prasarana umum yang belum memadai.

Berdasarkan hal tersebut dapat dirumuskan tujuan khusus dari penelitian ini adalah Untuk Mendiskripsikan potensi-potensi dan daya tarik wisata yang ada di pantai Pandawa dan untuk mengetahui persepsi wisatawan terhadap produk wisata yang terdapat pantai Pandawa yang nantinya bisa digunakan sebagai bahan pertimbangan dalam melakukan perbaikan pengelolaan Kawasan pantai Pandawa

\section{METODE PENELITIAN}

Jumlah sampel yang diambil sebanyak 5 kali jumlah variable sesuai dengan yang dikemukakan oleh Malholtra, (dalam Widayat 2004:27) jadi jumlah sampel 5 x $20=100$ orang wisatawan. Teknik yang digunakan adalah Accidental Sampling (Suharsimi Arikunto, 2015). Data dikumpulkan dengan metode servey, kuesioner, melakukan wawancara baik dengan pengelola maupun dengan wisatawan. Data dianalisis dengan teknik analisis kuantitatif, yaitu teknik analisis untuk menganalisa data kuantitatif dengan menggunakan statistik deskriptif yang digunakan untuk mengukur sifat, pendapat dan persepsi seseorang atau sekelompok orang tentang fenomena sosial (Umar, 2005:69). Berhubungan penelitian ini di pantai Pandawa terdapat banyak ada potensi yang belum dikembangan secara optimal yang berupa rumput laut, terumbu karang dan tebing yang menakjubkan.

\section{HASIL DAN PEMBAHASAN}

\section{Letak Dan lokasi Pantai Pandawa Bali}

Pantai Pandawa Bali merupakan tempat wisata populer terbaru yang berada di wilayah ujung selatan pulau Bali, di mana Pantai Pandawa atau kalau orang bule menyebutnya Pandawa beach, terletak di Desa Kutuh, kecamatan Kuta Selatan, Kabupaten Badung. Jarak tempuh pantai pandawa jika dari airport Ngurah Rai adalah 18 km. Kurang lebih satu jam tergantung kemacetan di perjalanan. Hal yang menarik mengenai letak dari lokasi pantai pandawa adalah berada di balik tebing, sehingga pantai ini di sebut dengan secret beach, atau pantai tersembunyi. Banyak orang memang menilai pantai 
pandawa di Bali ini sebagai sebuah surga yang tersembunyi, sehingga mereka tergoda untuk segera bertamasya ke pantai Pendawa di Bali ini.

Sebelum masuk ke area Pantai Pandawa, kita akan disuguhkan dengan pemandangan tebing kapur yang menjulang tinggi di kiri dan kanan jalan dan pemandangan pantai yang indah di depannya menanti. Pantai Pandawa terletak di ujung paling selatan pulau Bali dimana pada wilayah ini pantai-pantainya terkenal sebagai pantai-pantai dengan pasir putih kekuningan yang bersih dan lembut, air laut yang jernih serta cukup jauh dari keramaian. Saat laut surut, pemandangan di Pantai Pandawa ini akan terlihat lebih indah dibandingkan saat pasang.

Tebing yang terletak di sekitar Pantai Pandawa ini dipahat 5 patung Pandawa dan Kunti, itulah sebabnya pantai ini akhirnya dinamakan Pantai Pandawa (Pandawa Beach). Patung-patung tersebut dapat dilihat setelah melewati papan nama Pantai Pandawa yang berwarna jingga. Patung-patung ini terukir di tebing sebelah kiri jalan, mulai dari patung Dewi Kunti, dilanjutkan dengan 5 Pandawa diantaranya patung Dharma Wangsa (nama lain Yudistira), patung Bima, patung Arjuna, patung Nakula dan patung Sahadewa yang merupakan tokoh utama dari kisah Mahabarata. Masing-masing dari patung tersebut memiliki tinggi mencapai 5 meter dengan lebar 2,5 meter yang gambarnya seperti di bawah.

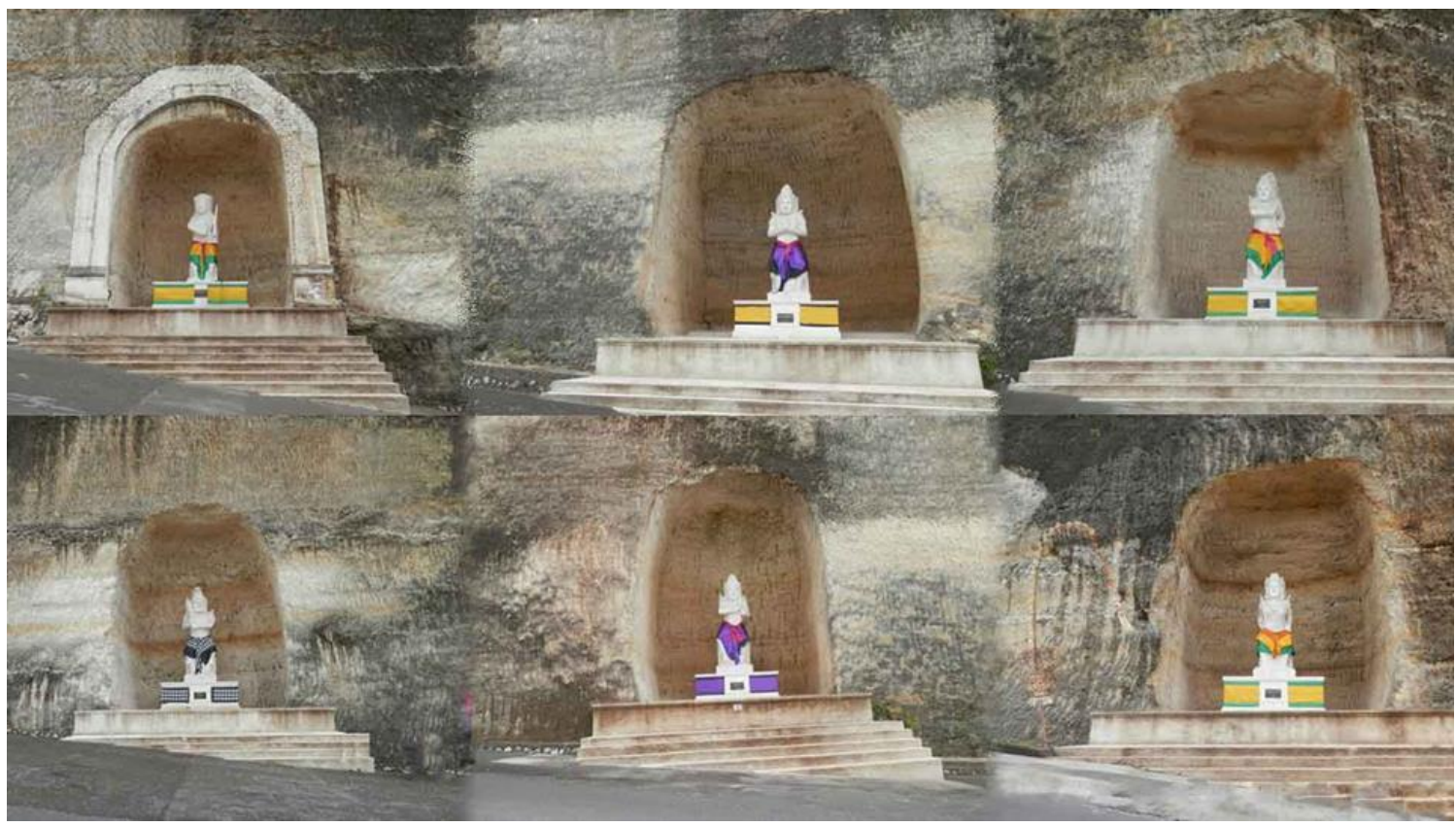

\section{Gambar 4.1 Patung Pandawa Lima Di Tebing Pantai Pandawa Bali}

Keberadaan patung-patung ini diambil dari salah satu penggalan kisah mahabarata saat kelimapendawa ini dikurung dalam Goa gala-gala. Kelima pandawa berhasil selamat setelah mereka membuat sebuah terowongan yang berujung ke sebuah hutan belantara. Di hutan ini, kemudian keluarga pandawa mendirikan kerajaan Amertha. Cerita itulah ini yang menjadi 
inspirasi oleh masyarakat sekitar pantai pandawa. Mereka melambangkan filosofi dari keberadaan pantai pandawa yang dulunya tersembunyi di balik tebing, hingga akhirnya dibuatkan jalan sehingga kini pantai pandawa ini bisa memberi manfaat dan seolah menjadi kerajaan baru bagi masyarakat sekitar.

Pantai Pandawa memiliki panjang mencapai 2 kilometer yang dibatasi oleh tebing kapur yang tinggi, sehingga pemandangan dari atas tebing maupun dari bawah tebing akan terlihat sangat menawan. Pantai Pandawa juga saat ini dapat diakses dengan mudah karena jalan menuju pantai ini cukup mulus.

\section{Potensi dan Daya Tarik Pantai Pandawa}

Pantai Pandawa mempunyai berbagai Potensi yang bisa dikembangkan menjadi obyek dan daya tarik wisata serta menjadi media untuk melakukan atraksi wisata, yang meliputi: 1) Tebing kapur yang menjulang tinggiyang ada di pinggir pantai Pandawa merupakan pemandangan yang sangat menarik, sehingga potensi ini bisa menjadi obyek wisata alam. 2) Pantai yang berpasir putih yang terbentang seluas 2 KM di kawasan pantai Pandawa yang dihiasi dengan pasir putih kekuningan yang luas dan mempesona, merupakan daya Tarik bagi wisatawan yang mengunjungi pantai Pandawa. Pantai dengan pasir putih kekuningan memberikan nuansa yang sangat ceria, sehingga sangat potensial dikembangkan beberapa atraksi dan usaha wisata, yang berupa: para sailling dan usaha wisata yang berupa: penyewaan long chair, payung pantai dan pijit tradisional. 3) Rumput Laut, di mana sebelum pantai Pandawa di buka, yaitu tahun 2012, usaha masyarakat di desa Kutuh kebanyakan sebagai nelayan dan berbudi daya rumput laut. Rumput laut yang dibudi dayakan di laut Melasti (sebelum diberi nama Pantai Pandawa) merupakan sumber penghasilan dari masyarakat di desa Kutuh. Di mana rumput laut yang dihasilkan dijual kepada para pedagang minuman dan rujak, bahkan sebagian ada yang diekspor. Rumput laut yang dihasilkan sangat potensial dikembangkan menjadi berbagai jajanan atau kue dan berbagai minuman yang bisa dikemas menjadi oleh-oleh bagi wisatawan yang mengunjungi pantai Pandawa, atau bisa dinikmati langsung pada saat kunjungan. Budi daya rumput laut bisa dijadikan sebagai atraksi agro wisata laut yang dapat dinikmati oleh wisatawan, mulai dari penanaman, pemeliharaan, panen, dan pengolahan rumput laut. 4) Laut biru yang jernih, dimana pemandangan laut pantai Pandawa yang tenang dan bersahabat dengan gelombang yang tidak begitu besar yang memanjakan mata, apalagi pada sore hari dengan sun set-nya sangat menakjubkan. Potensi laut yang ada di pantai Pandawa sangat potensial dikembangkan beberapa produk wisata, yang berupa berbagai usaha yang meliputi: penyewaan kano, penyewaan perahu pancing, dan surfing yang merupakan atraksi wisata laut. 5) Taman terumbu karang (Coral garden) yang masih perawan, di mana untuk kedepannya potensi terumbu karang yang ada di pantai Pandawa sangat strategis untuk dikembangkan menjadi obyek dan atraksi wisata diving dan snorkeling, mengingat lokasi pantai Pandawa sangat dekat dengan kawasan wisata yang popular, yaitu dekat dengan kawasan Nusa Dua dan kawasan wisata Kuta. Adapun gambar dari semua potensi tersebut adalah seperti di bawah. 

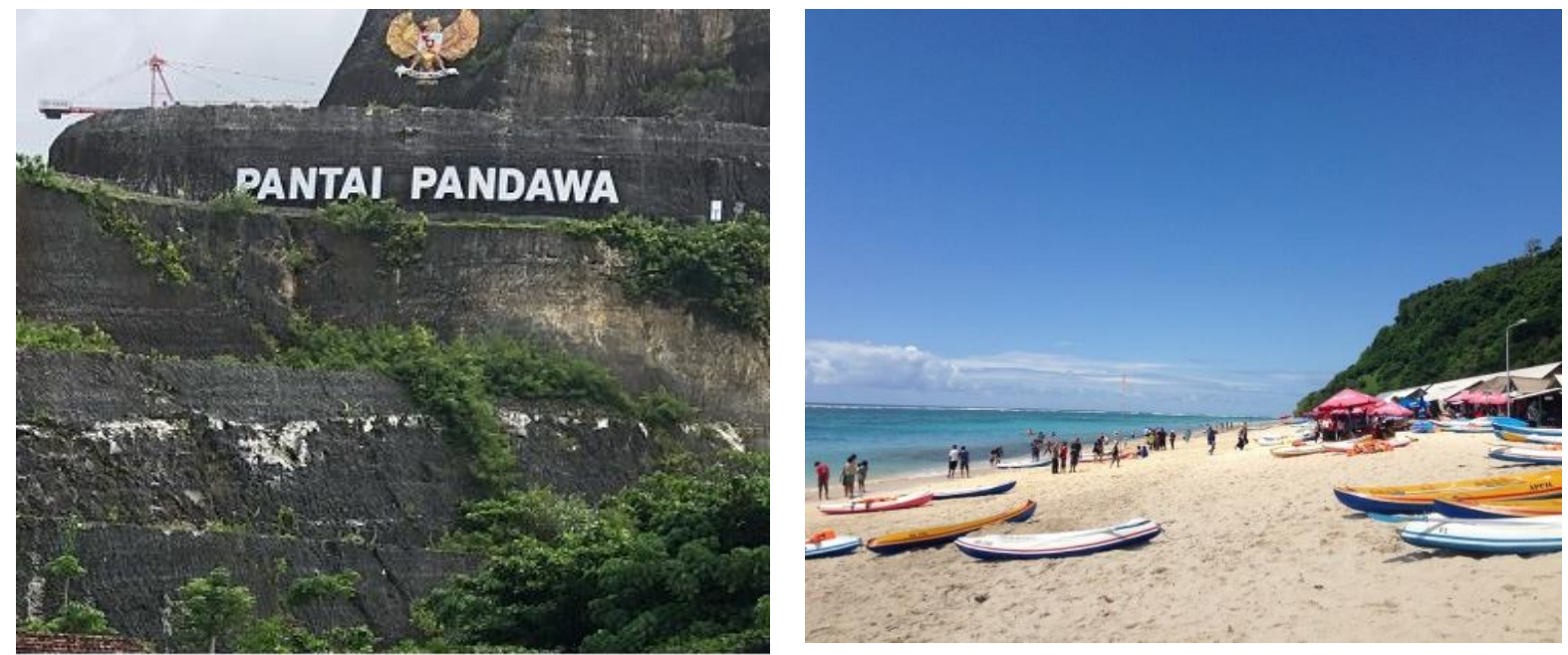

Tebing Kapur

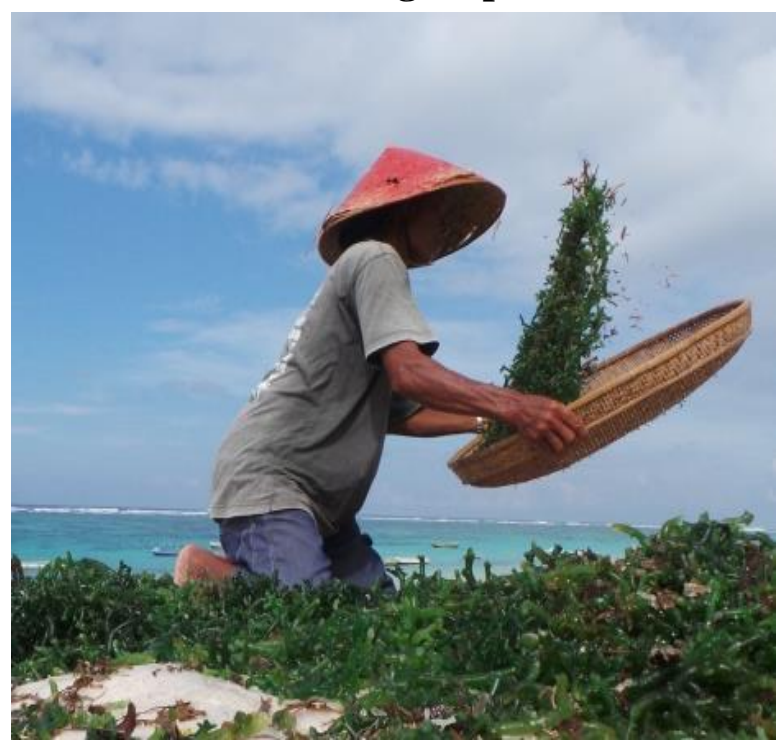

Penyiangan Rumput Laut

Gambar
Laut dan Pantai Pandawa

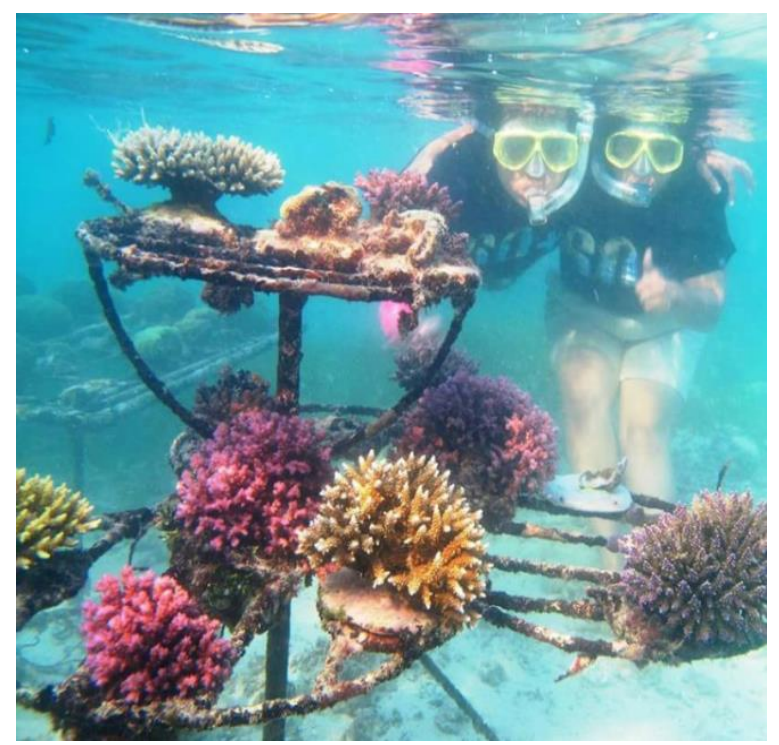

Terumbu Karang

Potensi alam Pantai Pandawa

Untuk potensi sosial budaya yang merupakan potensi yang terdapat di kehidupan masyarakat desa Kutuh yang berupa berbagai jenis kesenian daerah dan adat istiadat. Di mana masyarakatnya masih melestarikan tari tradisional dan tari pertunjukkan yang berupa Sendratari Ramayana yang secara rutin di pentaskan pada saat upacara di Pura Kahyangan Tiga (Pura Desa, Pura Puseh, dan Pura Dalem) di desa Kutuh. Tari ini juga sering dipentaskan di stage pantai Pandawa bersamaan dengan tari kecak dan tari barong. Terdapat juga adat istiadat yang berupa upacara adat dan tradisi yang berupa upacara kremasi yang mempunyai daya tarik tersendiri yang bisa disaksikan oleh wisatawan serta sistem gotong royong yang masih lestari. Begitu juga terdapat benda-benda budaya yang berupa pura dengan bangunan stil Bali dengan ornamennya dan terdapat patung Dewi Kunti dan Panca Pandawa di tebing sepanjang jalan menuju pantai Pandawa. Di pantai pandawa ada pula satu kawasan pantai yang disucikan oleh penduduk lokal. Setidaknya terdapat enam area yang 
disucikan dikawasan ini, yakni area batu cupid, tempat upacara melasti, pura dalem segara, sumur sumber air minum penduduk desa, sawan wela, dan sawan sambang.

Sedangkan untuk potensi sumber daya manusia yang ada di desa Kutuh, di mana masyarakat yang sudah berusia tua yang awalnya sebagai nelayan dan petani rumput laut, sekarang sebagian besar beralih profesi sebagai wira usaha penyedia sarana pariwisata. Di mana mereka semua diperdayakan dalam pengembangan obyek wisata Pantai Pandawa. Usaha yang dilakukan mereka berupa penyewaan kano, kursi panjang, perahu mancing, usaha pijak tradisional, menjual souvenir, dan usaha kuliner (makanan dan minuman). Semua usaha yang menyediakan produk wisata yang merupakan sarana pariwisata dilakukan oleh masyarakat lokal desa Kutuh di bawah pengaturan dari manajemen obyek wisata Pantai Pandawa. Sedangkan Generasi muda sebagaian besar masih menempuh pendidikan, sehingga sangat potensial untuk pengembangan pantai Pandawa secara efektif kedepannya menjadi obyek wisata yang popular. Apalagi dari yang masih menempuh pendidikan, sebagian besar mengambil bidang studi pariwisata.

Dengan melihat potensi yang ada di pantai Pandawa, dan berdasarkan analisis kreteria produk wisata kreatif, yaitu bersifat inovatif , berbasis kreativitas masyarakat, dan didukung dengan kemampuan menggunakan teknologi yang melibatkan wisatawan, maka ada dua produk wisata yang bersifat kreatif yang akan dikembangkan kedepannya, yaitu:

\section{a. Museum Bahari}

Museum Bahari adalah museum yang menyimpan koleksi yang berhubungan dengan kebaharian dan kenelayanan. Sebelum dibukanya pantai Pandawa sebagai obyek dan kawasan wisata pada tahun 2012, mata pencaharian masyarakat desa Kutuh Kuta Selatan kebanyakan sebagai petani rumput laut dan banyak yang berprofesi sebagai nelayan. Tetapi dengan perkembangan pantai Pandawa sebagai kawasan wisata yang sangat pesat, profesi itu ditinggalkannya dan beralih profesi sebagai pelaku bisnis priwisata dan pekerja di sektor pariwisata.

Untuk mengingatkan keberadaan masyarakat desa Kutuh kepada generasi muda yang akan datang dan dapat berfungsi sebagai produk wisata, maka ada ide untuk mengembangkan produk wisata berupa museum Bahari Pandawa. Walaupun kunjungan wisatawan ke museum masih kecil, namun sarana pariwisata ini dapat memperkaya variasi produk wisata yang ada di pantai Pandawa.

Sesuai dengan strategi pemasaran, di mana makin banyak variasi produk yang ditawarkan makin banyak penjualan yang bisa tercapai. Sehingga dengan bertambah banyaknya produk wisata yang ditawarkan di pantai Pandawa, maka ada kecendrungan akan terjadinya peningkatan kunjungan wisatawan. Koleksi yang akan dipajang di museum ini adalah peralatan dan perlengkapan para petani rumput laut dan para nelayan.

\section{b. Wisata Budi Daya dan Kuliner Rumput Laut}

Walaupun keberadaan petani rumput laut yang ada di pantai Pandawa sudah beralih fungsi dan para generasi muda tidak ada lagi yang mau terjun sebagai penatni rumput, tetapi potensi raumput laut yang ada di pantai Pandawa masih eksis. Dengan melihat potensi 
rumput laut yang potensial untuk dikembangkan sebagai obyek dan daya tarik wisata, maka pihak manajemen pantai Pandawa ada ide kedepannya untuk memperdayakan masyarakat untuk memanfaatkan potensi tersebut. Sistem yang diterapakan dalam menghidupkan kembali petani rumput laut adalah dengan sistem perburuhan, di mana masyarakat yang mau menjadi petani rumput laut akan digaji bulanan atau diberikan upah harian, sehingga ada atraksi wisata yang berupa budi daya rumput laut yang ditawarkan kepada wisatawan dan wisatawan bisa terlibat dalam prosesi budi daya tersebut. Sedangkan hasil budi daya rumput laut tersebut bias dijual kepada pedagang lokal, diekspor, bahkan bisa diolah menjadi produk wisata kuliner.

\section{Persepsi wisatawan terhadap kondisi alam pantai Pandawa}

Dalam menentukan persepsi wisatawan terhadap produk wisata yang terdapat di pantai Pandawa digunakan rentang nilai dalam berbagai katagori sebagai dasar penilaian. Dimana persepsi wisatawan terhadap produk wisata yang terdapat di pantai Pandawa meliputi persepsi wisatawan terhadap kondisi lingkungan alam, sosial budaya, prasarana umum, dan sarana pariwisata yang merupakan komponen produk wisata. Adapun rentang nilai yang digunakan adalah sebagai berikut:

Tabel 1

\section{Rentangan Penilaian Persepsi}

\begin{tabular}{|c|c|c|}
\hline Nilai & Rentang nilai & Kriteria \\
\hline 4 & $3,26-4,00$ & Sangat baik \\
\hline 3 & $2,51-3,25$ & Baik \\
\hline 2 & $1,76-2,50$ & Cukup \\
\hline 1 & $1,00-1,75$ & Kurang \\
\hline
\end{tabular}

\section{Persepsi Wisatawan Terhadap Alam Pantai Pandawa}

Mengenai persepsi wisatawan terhadap kondisi lingkungan alam yang terdapat di pantai Pandawa dapat diketahui dari tabel berikut:

Tabel 2

Persepsi Wisatawan Terhadap Alam Pantai Pandawa

\begin{tabular}{|c|c|c|c|c|c|c|c|}
\hline \multirow{2}{*}{ No. } & \multirow{2}{*}{ Unsur Alam } & \multicolumn{6}{|c|}{ Persepsi Wisatawan } \\
\hline & & Domes & Ket. & Asing & Ket. & Rata2 & Ket. \\
\hline 1 & Keindahan & 3.57 & Sg. Baik & 3.63 & Sg. Baik & 3.60 & Sg. Baik \\
\hline 2 & Kebersihan & 3.17 & Baik & 2.70 & Baik & 2.94 & Baik \\
\hline 3 & Kesejukan & 2.87 & Baik & 3.13 & Baik & $3,-$ & Baik \\
\hline 4 & Kenyamanan & 3.33 & Baik & 3.13 & Baik & 3.23 & Baik \\
\hline \multicolumn{2}{|c|}{ Rata-rata Total } & 3.23 & Baik & 3.14 & Baik & 3.19 & Baik \\
\hline
\end{tabular}

Berdasarkan tabel di atas, di mana dari empat komponen alam yang tersedia di pantai Pandawa, hanya satu unsur yang berupa keindahan menunjukkan kondisinya sangat 
baik berdasarkan persepsi wisatawan baik wisatawan domestik maupun wisatawan asing. Kondisi keindahan yang terdapat di lingkungan pantai pandawa ini akan dapat menciptakan obyek wisata pantai Pandawa menjadi obyek wisata yang populer. Sehingga akan mendorong pengembangan komponen produk wisata lainnya, seperti berkembangannya pembangunan hotel di wilayah desa Kutuh yang menaungi pantai Pandawa. Sedangkan persepsi wisatawan baik domestik maupun asing terhadap unsurunsur alam lainnya dalam katagori baik. Begitu juga secara keseluruhan kondisi alam pantai Pandawa setelah dianalisis menunjukkan dalam katagori baik.

\section{Persepsi wisatawan terhadap kondisi sosial budaya}

Mengenai persepsi wisatawan terhadap kondisi sosial budaya yang terdapat di desa Kutuh yang menaungi pantai Pandawa, terutama yang berkaitan dengan adat istiadat dan seni budaya yang berlaku di desa Kutuh. Begitu juga mengenai keramahan penduduk dan upacara adat yang dijalankan dapat diketahui dari tabel berikut:

Tabel 3

Persepsi Wisatawan Terhadap Kondisi Sosial Budaya

\begin{tabular}{|c|l|r|c|c|c|c|c|}
\hline \multirow{2}{*}{ No. } & \multirow{2}{*}{ Unsur Sosial Budaya } & \multicolumn{7}{|c|}{ Persepsi Wisatawan } \\
\cline { 3 - 8 } & & Dmk & Ket. & Asing & Ket. & Rata2 & Ket. \\
\hline 1 & Keramahan & 3.35 & S.Baik & 3.43 & S.Baik & 3.39 & S.Baik \\
\hline 2 & Keamanan & 3.47 & S.Baik & 3.03 & Baik & 3.25 & Baik \\
\hline 3 & Ketertiban & 3.25 & Baik & 2.95 & Baik & 3.10 & Baik \\
\hline 4 & Ornamen budaya & 2.98 & Baik & 3.08 & Baik & 3.03 & Baik \\
\hline 5 & Atraksi budaya & 2.26 & kurang & 3.05 & Baik & 2.66 & Baik \\
\hline 6 & Kegiatan upacara & 2.57 & Baik & 2.70 & Baik & 2.64 & Baik \\
\hline & Rata-rata Total & 3.04 & Baik & 3.04 & Baik & 3.04 & Baik \\
\hline
\end{tabular}

Berdasarkan tabel di atas, di mana dari enam unsur sosial budaya yang berlaku di desa Kutuh, ada dua unsur yang sangat baik dari perspsi wisatawan domestik, yaitu unsur keramahan dan keamanan. Sedangkan tiga unsur lainnya, yaitu: ketertiban, ornament budaya, dan kegiatan upacara baru dalam katagori baik, dan ada satu unsur, yaitu atraksi budaya yang masih kurang. Namun dilihat dari persepsi wisatawan asing, hanya ada satu unsur yang sangat baik, yaitu unsur keramahan masyarakatnya, sedangkan lima unsur lainnya baru dalam katagori baik. Dari seluruh unsur sosial budaya, di mana persepasi wisatawan domestik maupun asing baru dalam katagori baik, sedangkan secara keseluruhan perpsepsi wisatawan terhadap kondisi sosial budaya yang berkaitan dengan pantai Pandawa juga dalam kondisi baik. Kondisi ini cukup mendorong para pengusaha yang bergerak di sektor industri pariwisata untuk berinvestasi di wilayah desa Kutuh, terutama di sekitar pantai Pandawa. 


\section{Persepsi wisatawan terhadap kondisi prasarana umum}

Mengenai persepsi wisatawan terhadap kondisi prasarana yang terdapat di pantai Pandawa, terutama yang berkaitan dengan aksesibilitas dan prasarana umum lainnya, dapat diketahui dari tabel 4

Berdasarkan tabel 4, di mana dari delapan unsur prasarana umum, hanya ada satu unsur, yaitu: area parkir yang menunjukkan dalam katagori sangat baik yang dilihat dari persepsi wisatawan domestik. Sedangkan tujuh unsur lainnya baru dalam katagori baik, begitu juga persepsi wisatawan domestik terhadap kondisi prasarana umum secara keseluruhan dalam katagori baik. Namun persepsi wisatawan asing terhadap prasarana umum terdapat 9 unsur yang perspsinya sangat ekstrim sekali, di mana ada yang sangat baik dan ada yang sangat kurang. Unsur prasarana umum yang sangat baik ada dua unsur, yaitu aksesibilitas menuju

Tabel 4

\section{Persepsi Wisatawan Terhadap Prasarana Umum}

\begin{tabular}{|c|l|c|c|c|c|c|c|}
\hline \multirow{2}{*}{ No. } & \multirow{2}{*}{$\begin{array}{c}\text { Unsur Prasarana } \\
\text { Umum }\end{array}$} & \multicolumn{6}{|c|}{ Persepsi Wisatawan } \\
\cline { 3 - 8 } & Dmk & Ket. & Asing & Ket. & Rata2 & Ket. \\
\hline $\mathbf{1}$ & Aksesibilitas & 3.25 & Baik & 3.48 & S.Baik & $\mathbf{3 . 3 7}$ & S.Baik \\
\hline $\mathbf{2}$ & Area parkir & 3.45 & S.Baik & 3.50 & S.Baik & $\mathbf{3 . 4 8}$ & S.Baik \\
\hline $\mathbf{3}$ & Ketersediaan air bersih & 2.98 & Baik & 3.10 & Baik & $\mathbf{3 . 0 4}$ & Baik \\
\hline $\mathbf{4}$ & Penerangan & 2.87 & Baik & 2.10 & Baik & $\mathbf{2 . 4 9}$ & Cukup \\
\hline $\mathbf{5}$ & Toilet umum & 2.83 & Baik & 1.95 & Cukup & $\mathbf{2 . 3 9}$ & Cukup \\
\hline $\mathbf{6}$ & Money changer & - & - & 1.75 & Kurang & $\mathbf{1 . 7 5}$ & Kurang \\
\hline $\mathbf{7}$ & Fasilitas kesehatan & 2.80 & Baik & 2.20 & Cukup & $\mathbf{2 . 5 0}$ & Cukup \\
\hline $\mathbf{8}$ & Pusat informasi wisata & 2.97 & Baik & 2.60 & Baik & $\mathbf{2 . 7 9}$ & Baik \\
\hline $\mathbf{9}$ & Pos keamanan & 3.22 & Baik & 2.68 & Baik & $\mathbf{2 . 9 5}$ & Baik \\
\hline & Rata-rata Total & $\mathbf{3 . 0 5}$ & Baik & $\mathbf{2 . 3 0}$ & Cukup & $\mathbf{2 . 6 8}$ & Baik \\
\hline
\end{tabular}

pantai Pandawa dan area parkir, sedangkan yang sangat buruk, belum adanya money changer di pantai Pandawa dan daerah sekitar desa Kutuh. Persepsi wisatawan asing terhadap prasarana umum di pantai Pandawa dalam katagori kurang, sedangkan secara keseluruhan persepsi wisatawan yang mengunjungi pantai Pandawa terhadap prasarana umum yang ada baru dalam katagori baik. Kondisi ini perlu disikapi oleh pengelola obyek wisata pantai Pandawa dengan berbagai pembenahan, walaupun tidak begitu parah. Karena kondisi yang berkaitan dengan prasaran umum sangat mempengaruhi keamanan dan kesehatan dari wisatawan yang mengunjungi pantai Pandawa.

\section{Persepsi wisatawan terhadap kondisi sarana pariwisata}

Mengenai persepsi wisatawan terhadap kondisi sarana pariwisata yang ada di pantai Pandawa dan sekitarnya, hanya dilihat dari persepsi wisatawan terhadap sarana pariwsata yang dikelola oleh manajemen pantai Pandawa. Adapun persepsi wisatawan dapat diketahui pada tabel berikut ini: 
Tabel 5

\section{Persepsi Wisatawan Terhadap Sarana Pariwisata}

\begin{tabular}{|c|l|c|c|c|c|c|c|}
\hline \multirow{2}{*}{ No. } & \multirow{2}{*}{$\begin{array}{c}\text { Unsur Sarana } \\
\text { Pariwisata }\end{array}$} & \multicolumn{6}{|c|}{ Persepsi Wisatawan } \\
\cline { 3 - 8 } & & Dmk & Ket. & Asing & Ket. & Rata2 & Ket. \\
\hline $\mathbf{1}$ & Angkutan wisata & 2.97 & Baik & 2.70 & Baik & $\mathbf{2 . 8 4}$ & Baik \\
\hline $\mathbf{2}$ & Kualitas restoran & 3.02 & Baik & 3.10 & Baik & $\mathbf{3 . 0 6}$ & Baik \\
\hline $\mathbf{3}$ & Atraksi pantai & 2.97 & Baik & 2.98 & Baik & $\mathbf{2 . 9 8}$ & Baik \\
\hline $\mathbf{4}$ & Toko sovenir & 2.98 & Baik & 3.03 & Baik & $\mathbf{3 . 0 1}$ & Baik \\
\hline $\mathbf{5}$ & Usaha pijak & 2.92 & Baik & 3.25 & Baik & $\mathbf{3 . 0 9}$ & Baik \\
\hline & Rata-rata Total & $\mathbf{2 . 9 7}$ & Baik & $\mathbf{3 . 1 0}$ & Baik & $\mathbf{3 . 0 4}$ & Baik \\
\hline
\end{tabular}

Berdasarkan tabel di atas, di mana persepsi wisatawan baik domestik maupun asing terhadap kelima unsur sarana pariwisata menunjukkan dalam katagori baik. Begitu juga secara keseluruhan persepsi wisatawan terhadap sarana pariwisata yang ada di pantai Pandawa dalam katagori baik. Kondisi ini sangat mendukung kehidupan atau perkembangan sarana pariwisata yang merupakan usaha yang dijalankan oleh penduduk lokal desa Kutuh dibawah pengaturan dari pengelola pantai Pandawa.

\section{Kondisi Pantai Pandawa Secara keseluruhan}

Kondisi secara keseluruhan yang terjadi di pantai Pandawa merupakan hasil kalkulasi dari persepsi wisatawan baik domestik maupun asing terhadap komponen komponen produk wisata yang ada di pantai Pandawa. di mana kondisi secara keseluruhan dari semua komponen produk pariwisata (alam, sosial budaya, prasarana umum, dan sarana pariwisata) yang ada di pantai Pandawa dapat dilihat dari tabel di bawah

Tabel 6

\section{Kondisi Obyek Wisata Pantai Pandawa}

\begin{tabular}{|c|c|c|c|c|c|c|c|}
\hline \multirow{2}{*}{ No. } & \multirow{2}{*}{$\begin{array}{c}\text { Komponen } \\
\text { Prduk Wisata }\end{array}$} & \multicolumn{6}{|c|}{ Kondisi hasil persepsi } \\
\hline & & Domes & Ket. & Asing & Ket. & Rata2 & Ket. \\
\hline 1 & Alam & 3.23 & Baik & 3.14 & Baik & 3.19 & Baik \\
\hline 2 & Sosial budaya & 3.04 & Baik & 3.04 & Baik & 3.04 & Baik \\
\hline 3 & Prasarana umum & 3.05 & Baik & 2.30 & Kurang & 2.68 & Baik \\
\hline 4 & Sarana pariwisata & 2.97 & Baik & 3.10 & Baik & 3.04 & Baik \\
\hline \multicolumn{2}{|r|}{ Rata-rata Total } & 3.07 & Baik & 2.90 & Baik & 2.99 & Baik \\
\hline
\end{tabular}

Dari empat komponen produk wisata, semuanya menunjukkan kondisi dalam katagori baik, di mana yang paling baik adalah kondisi alam pantai Pandawa dengan nilai 3.19. Kemudian diikuti dengan kondisi sosial budaya dan sarana pariwisata dengan kondisi yang sama dengan niali 3.04, dan yang terakhir adalah kondisi prasarana umum dengan nilai 2.68. Melihat kondisi alam yang ada di pantai Pandawa yang terbaik dari komponen produk wisata lainnya, maka kawasan yang ada di pantai Pandawa sangat potensial dikembangkan menjadi obyek wisata yang populer. 
Berdasarkan kondisi produk wisata yang ada di pantai Pandawa, secara keseluruhan baru dalam katagori baik, maka dalam rangka meningkatkan popularitas obyek wisata pantai Pandawa ada beberapa hal yang perlu dilakukan berkaitan dengan pengelolaan kawasan pantai Pandawa kedepannya yang meliputi:

a. Menata lingkungan alam yang ada di pantai Pandawa, terutama meningkatkan kebersihan, dan perlu melakukan penanaman pohon pantai yang dapat memberikan kesejukan pada waktu siang hari. Disamping perlu adanya penataan taman yang ada disekitar area patung, sehingga memperindah ornament budaya yang ada di pinggir tebing yang memperindah nuansa menuju pantai Pandawa yang akan dapat menciptakan panorama yang lebih mempesona..

b. Perlu melestarikan adat istiadat yang ada dan meningkatkan kreasi seni budaya serta tetap melestarikan susunan rumah Bali yang kental dengan bangunan stil Bali yang akan memberikan keunikan dalam rangka menciptakan produk wisata yang mempunyai keunggulan komparatif.

c. Meningkatkan kapasitas, jumlah dan kualitas prasarana umum yang ada di pantai Pandawa yang sangat mempengaruhi kenyamanan wisatawan yang mengunjungi pantai Pandawa, apalagi pada musim ramai ( high season ). Melihat kondisi komponen produk wisata yang ada di pantai Pandawa ini sangat kurang di mata wisatawan asing, maka pengembangan prasarana umum dalam rangka meningkatkan kunjungan wisatawan perlu mendapatkan skala prioritas.

d. Meningkatkan jumlah dan kualitas sarana paraiwisata yang beroperasi di kawasan pantai Pandawa, terutama meningkatkan kualitas pelayanan yang dapat menjamin wisatawan dalam menggunakan sarana pariwisata merasa lebih aman, nyaman dan memuasakan. Dalam meningkatkan kunjunganan wisatawan yang datang ke pantai Pandawa, terutama wisatawan asing, maka perlu mengembangkan produk wisata minat khusus, mengingat banyak potensi alam yang belum dimanfaatkan secara optimal yang ada di pantai Pandawa. Di antara potensi yang ada di pantai Pandawa, yang belum digarap adalah terumbu karang yang masih perawan yang bisa digunakan sebagai obyek dan atraksi wisata bahari yang bersifat kreatif. Begitu juga potensi alam yang berupa tebing yang terbentang sepanjang $2 \mathrm{KM}$ yang yang memagari pantai Pandawa baru sebagian kecil dimanfaatkan. Sehingga dengan banyak tersedianya potensi alam yang ada di pantai Pandawa, memungkinkan dapat melakukan pengembangan diversifikasi produk wisata.

e. Merperbaiki manajemen lingkungan dan manajemen operasional pantai Pandawa yang berbasis profesionalisme, sehingga akan dapat memberikan pelayanan yang lebih memuaskan kepada wisatawan serta dapat memberikan nuansa yang lebih sejuk, nyaman, indah dan mempesona.

\section{KESIMPULAN}

Berdasarkan hasil analisis yang telah dilakukan dapat ditarik beberapa kesimpulan sebagai berikut: 
1. Potensi dan daya tarik yang terdapat di Pantai Pandawa yang bisa dikembangkan menjadi kawasan wisata atau produk wisata, meliputi: tebing kapur yang menjulang tinggI, pantai berpasir putih, rumput laut, laut biru yang jernih, taman terumbu karang (coral garden). Produk wisata kreatif yang bisa dikembangkan dengan melihat potensi yang ada di pantai Pandawa adalah museum bahari dan wisata budi daya dan kuliner rumput.

2. Persepsi wisatawaan terhadap kondisi alam pantai Pandawa secara keseluruhan dalam katagori baik, namun masih ada persepsi wisatawan asing dalam katagori cukup terhadap prasarana umum yang perlu mendapatkan perhatian manajemen pantai Pandawa. Maka dalam rangka meningkatkan popularitas kawasan pantai Pandawa, perlu melakukan beberapa hal sebagai berikut:

a. Menata lingkungan alam yang ada di pantai Pandawa

b. Perlu melestarikan adat istiadat yang ada dan meningkatkan kreasi seni budaya

c. Meningkatkan kapasitas, jumlah dan kualitas prasarana umum

d. Meningkatkan jumlah dan kualitas sarana paraiwisata

e. Merperbaiki manajemen lingkungan dan manajemen operasional pantai Pandawa yang berbasis profesionalisme

\section{DAFTAR PUSTAKA}

Bakkara, Riana UWK dan Sunantri, Y. (2012). Analisis Potensi Wisata Bahari Melalui Pendekatan CBT (Community Based Tourism) di Tanjung Utama Kota Batam. Universitas Internasional Batam.

Denis L Foster. (2000). Fist Class An Introduction to Travel \& Tourism (Second Edi). PT. Raja Grafindo.

Edward, I. (1991). Tourism Planning An Integrated and Sustainable Development Approach (Van Nostrand Reinhold (ed.)).

Erli. (2006). Pengembangan Kawasan Pesisir Kota Singkawang: Sebuah Pendekatan Pemasaran Kawasan. ITS.

Greg Richards. (2001). Cultural Attractions and European Tourism. Amazon.co.uk: Books.

Gunn, Clare A. (2002). Tourism Planning: Basics, Concepts, Cases, Taylor and Francis (Inc (ed.); Books).

Husein Umar. (2005). Metode Riset Bisnis. PT Gramedia Pustaka Utama.

Johnston C., J. L. and K. D. (1991). Coastal and Marine Tourism. Annals of Tourism, 18 No. $\underline{3,523-525 .}$

Latimer, K.S., E.A. Mahaffey, dan W. P. (2003). Duncan \& Prasse's Veterinary Laboratory Medicine Clinical Pathology. Blackwell Publishing, 179-182.

Mason, P. (2003). Tuirism Impacts, Planning and Managenent. P Elsevier ButterworthHeinemann Linancre House, Burlington.

Miller, M. and Ditton, R. D. (1986). Travel, Tourism and Marine Affairs, Coastal Zone. Management Journal.

Nurif, M. (2017). Mitigating risk of maritime regulatory changes: Oil tanker owners' perspective.

Oyewole, A., Sapp, J., Wilson, B., dan Oyewole, O. (2014). Potential Environmental Risks from Home Healthcare-Generated Municipal Solid Waste in Texas. International Journal of Business, Humanities and Technology, 4(3). 
Siti N. (2001). Rencana Pengembangan Fisik Kawasan Wisata Bahari di Wilayah Pesisir Indonesia. Bulettin Taman Dan Lanskap Indonesia. Perencanaan, Perancangan Dan Pengelolaan, 3 No. 2(Studio Arsitektur Pertamanan Fakultas Pertanian IPB Bogor).

Suharsimi, A. (2002). Prosedur Penelitian: Suatu Pendekatan Praktek (Revisi). PT Renika. Wirawan S. (2009). Pengembangan Objek Wisata Bahari Yang Berkelanjutan di Nusa Lembongan Kabupaten Klungkung. Universitas Udayana Denpasar.

Undang-Undang No 10 Tahun 2009 tentang Kepariwisataan

www.kompasiana.com/.../( 55 ...23 Mei 2014 ), potensi-pantai-pandawa-di-desa-kutuh-kabbadung-bali 